\title{
Bladder Cancer cM1 TNM Finding v8
}

National Cancer Institute

\section{Source}

National Cancer Institute. Bladder Cancer CM1 TNM Finding v8. NCI Thesaurus. Code C140384.

Bladder cancer with distant metastasis. (from AJCC 8th Ed.) 